\title{
THE EFFECT OF RELATIONSHIP QUALITY ON CUSTOMER RETENTION AND WORD-OF- MOUTH COMMUNICATION: AN EMPIRICAL STUDY ON CUSTOMERS OF MOBILE TELECOMMUNICATIONS ' COMPANIES AT DAKAHLIA GOVERNORATE OF EGYPT
}

\author{
Dr. Abd El-Aziz Ali Hassan, Faculty of Commerce, Mansoura University, Mansoura, EGYPT
}

dx.doi.org/10.18374/IJBS-14-1.6

\begin{abstract}
Due to the more and more increased completion in today's business, many companies are required to build long-term profitable relationship with customers by increasing relationship quality (satisfaction, trust and commitment) to achieve customer loyalty (customer retention and word - of mouth communication. Therefore, relationship marketing has become more and more important since last decade of 20th.century, especially in service industry. Therefore, this study is aimed to investigate the effects of relationship quality on customer retention and word of mouth communication, by focusing on customers of Egyptian mobile telecommunications sector. According to literature review, an analytical model is developed as a guidance to test the relationship between the research variables. A quantitative method with deductive approach is chosen in this research. In order to collect primary data, a questionnaire is designed and randomly data have been collected from 400 customers of the three Egyptian mobile telecommunications companies (Mobinil, Vodafone and Etisalat Misr) in Dakahlia' Governorate, Egypt. The findings shows that the Egyptian companies within the service industry of mobile telecommunication can achieve word-of-mouth communication through customer satisfaction and trust. The study also finds that the features of customer satisfaction have a stronger positive effect on word-of-mouth communication than the features of trust.
\end{abstract}

Keywords: Relationship Quality; Customer Satisfaction; Trust; Customer Retention; Word-of-Mouth Communication; Egyptian Mobile Telecommunication 